ISSN:2528-9527

E-ISSN : 2528-9535

YIl Year: 11

Cilt Volume: 17

Sayı Issue :38

Haziran June 2021

\title{
Sosyal Hizmet Bölümü Öğrencilerinde Sosyal İlişki Unsurlarının Algilanan Anne-Baba Tutumu ve Akademik Başarıya Göre Değerlendirilmesi ${ }^{1}$
}

\author{
DOI: $10.26466 /$ opus.784070 \\ *
}

\begin{abstract}
Kübra Küçükșen *
Doç. Dr., Necmettin Erbakan Üniversitesi, Sağllk Bilimleri Fakültesi. Konya / Türkiye

E-Posta: kubrakucuksen@erbakan.edu.tr

ORCID: $0000-0001-9248-9541$
\end{abstract}

\begin{abstract}
$\ddot{O} z$
Bu araştırmanın amacı sosyal hizmet bölümü lisans öğrencilerinde sosyal ilişki unsurlarının bazı değişkenlerle ilişkisini incelemektir. Araştırmanın örneklemi Konya'da 3 farklı üniversitede Sosyal Hizmet Bölümünde lisans öğrenimi gören 310 öğrenciden oluşmaktadır. Araştırmada katılımcıların demografik bilgilerini içeren kişisel bilgi formu ile sosyal ilişki unsurları ölçeği kullanılmıştır. Veriler e-posta ve SMS ile http://www.surveey.com portal üzerinden toplanmıştır. Elde edilen veriler SPSS programı kullanılarak analiz edilmiştir. Araştırmamız sonucunda akademik başarı seviyesi ve anne baba tutumları ile öğrencilerin sosyal ilişki unsurları arasında istatistiksel açıdan anlamlı bir ilişki olduğu tespit edilmiştir ( $p<0.05)$. Güven verici, destekleyici ve hoşgörülü tutum sergileyen anne babaya sahip öğrencilerin daha fazla sosyal ilişki geliştirdikleri, daha fazla aile ve arkadaş desteği aldıkları tespit edilmiştir. Başarı seviyesi ile aile desteği alt boyutu puan ortalamalarında herhangi bir farklılaşma görülmezken arkadaş desteği alt boyutunda anlamlı bir ilişki bulunmuştur. Başarı düzeyi yüksek olan öğrencilerin arkadaş desteği puan ortalamaları daha yüksektir $(p<0.05)$. Gelir düzeyi, sosyal medya kullanım sıklı̆̆ ile sosyal ilişki unsurları puan ortalamaları arasında istatistiksel açıdan anlamlı bir ilişki tespit edilememiştir.
\end{abstract}

Anahtar Kelimeler: Sosyal İlişki, Sosyal Destek, Aile Desteği, Arkadaş Desteği

\footnotetext{
${ }^{1}$ Bu çalışma Uygulamalı Araştırma I-Il dersi kapsamında yürütülen saha çalışmasının verilerinden üretilmiştir.
} 


\title{
Evaluation of Social Relationship Elements in Social Work Department Students According to Perceived Parental Attitude and Academic Achievement
}

\begin{abstract}
The purpose of this research is to examine the relation between the social relation factors and some variables in students educating in departments of social work. The sample of the study consists of 310 students who study undergraduate in Social Work Department in 4 different universities in Konya. In the study, the personal information form containing demographic information of the participants and Provision for Social Relations (PSR) Scale were used. The data were collected via e-mail and SMS via $h t t p: / / w w w . s u r v e e y . c o m$ portal. The data obtained were analyzed using the SPSS program. According to the findings of the study, it was determined that there is a statistically significant relationship between the level of achievement and parental attitudes and the social relationship elements of the students $(p<0.05)$. It has been determined that students with a assuring, supportive and tolerant parents develop more social relationships and receive more family and friend support. While there was no difference? in the mean scores of the success level and the family support sub-dimension, a significant relationship was found in the friend support sub-dimension. Students with high level of success have higher mean scores on friend support $(p<0.05)$. No statistically significant correlation was found between income level, frequency of social media use and social relationship factors average scores.
\end{abstract}

Keywords: Social Relationship, Social Support, Family Support, Friend Support 


\section{Giriş}

Biyo-psiko sosyal bir varlık olarak dünyaya gelen her insan fizyolojik ve güvenlik gibi temel ihtiyaçlarını karşıladıktan sonra sevgi- ilgi görmek, aidiyet hissetmek, bir gruba üye olmak, kendi türüyle iletişim kurmak, bulunduğu çevrede saygı görmek, kendini gerçekleştirmek gibi ihtiyaçlarının karşılanmasına gereksinim duymaktadır. Cüceloğlu'na göre (1997,s.22) insan iki temel gereksinimle dünyaya gelmektedir. İlki bağımsız olma, güçlü olma, birey olma ihtiyaçlarına karşılık gelen "ben olma" ihtiyacı iken; ikincisi kendisinden daha güçlü ve daha büyük bir şeye ait olma ihtiyacına karşılık gelen "biz olma" gereksinimidir. Bu nedenle bir yandan fiziksel olarak gelişimi tamamlanırken diğer taraftan içinde yaşadığı topluma aidiyet geliştirerek toplumun normları davranış örüntüleri ile bütünleşmekte ve kendi sosyal ilişki ağlarını oluşturmaktadır. Ait olma ihtiyacının giderilmesi sosyal ilişkilerle gerçekleşmektedir ( Baumeister ve Leary, 1995).

Diğer varlıkların içgüdüsel olarak oluşturdukları topluluk ve toplu yaşamın aksine insan, aklı ve düşünme yeteneği sayesinde sürekli değişen gelişen bir toplumsal yaşam oluşturmaktadır (Arslantürk ve Amman, 2017, s.180). Toplumsal yaşam insanların ilişki, iletişim ve etkileşim halinde olması ile inşa edilmektedir. Bireyin ihtiyaç duyduğunda içinde bulunduğu çevreden alabileceği her türlü duygusal ve sosyal destek bu ilişkiler ağı sayesinde mümkün olmaktadır. Sosyal destek; "bireyin çevresinden gördüğü ilgi, sevgi, saygı, takdir ve güvenin yanı sıra, bilgi edinme ve maddi yardım gibi sosyal, psikolojik ve ekonomik nitelikli destek" olarak tanımlanmaktadır (Budak, 1999; Yıldırım, 2006; Ekinci ve Ekici, 2003). Sağlıklı ilişki ve destek ağlarına sahip olma kişilik gelişimi ve mutlu bir hayat sürdürmeye katkı sağlayan en önemli faktörlerdendir. Bireyin ailesiyle arkadaşlarıyla ve içinde bulunduğu toplumla oluşturduğu sosyal ilişkiler ve aldığı sosyal destek, bireyin karşılaştığı her türlü olumsuz durumlar karşısında bir tampon gibi koruma etkisi göstermekte (Lin, Thompson ve Kaslow, 2009), özgüven, benlik saygısı, ait olma vb. duygularının pozitif yönde gelişimine ve sağlıklı bir yaşam kalitesine ulaşabilmesine katkı sağlamaktadır (Atik, Çoban, Çok, Doğan, Karaman, 2014; Özyurt, 2007). Literatüre göre sosyal destek, kuramsal olarak aile, arkadaşlar ve birey için anlamlı diğer kişiler (akraba, komşu vb.) olmak üzere üç farklı kaynaktan elde edilmektedir (Çeçen, 2008; Zimet, Dahlem, Zimet ve Farley, 1988). İnsanın birincil destek aldığ 
kurumların başında aile gelmektedir. Tüm kültürlerde aile insanların maddi manevi gereksinimleri için ilk başvurdukları yaşam boyu destek kaynağı olarak işlev görülmektedir. Daha sonra okul veya iş arkadaşları, yüz yüze birincil ilişkiler kurulan diğer kişilerle destek alınabilecek ağ genişlemektedir.

Gelişim dönemlerine göre çocuğun ailede karşılanması gereken bir takım gereksinimleri bulunmaktadır. Değerli olma duygusu, güven, yakınlık ve dayanışma, sorumluluk, zorluklarla mücadele ederek üstesinden gelmeyi öğrenme, mutluluk ve kendini gerçekleştirme, manevi yaşamın temellerini oluşturma gibi temel gereksinimler (Cüceloğlu, 1998, s.51-53) sağlıklı bir şekilde giderilmezse sonraki dönemlerde "birey" olarak kişinin sağlıklı ilişkiler kurması ve sosyal iletişim ağlarını genişletmesi mümkün olmamaktadır. Anne baba tutumları, bireylerin yetişkinlik dönemlerinde özel hayat ve sosyal yaşamlarında geliştirecekleri ilişkilerde belirleyici bir özelliğe sahiptir (Palut 2008, s. 4). Bu nedenle ailede sağlıklı bir iletişim ile anne baba tutumlarının geliştirici destekleyici yönde olması son derece önem arz etmektedir. Çocuğa koşulsuz olarak değer ve güven verildiği, kendi yaşamına yön verebilecek irade gücü ve sorumluluk duygusu geliştirmesine imkân veren olanakların oluşturulduğu geliştirici aile ortamları, anne babanın sevgiye dayall, hoşgörülü ve destekleyici tutum sergilemesiyle mümkündür.

Bireyin dış dünyadan aldığı diğer önemli destek mekanizmalarından biri de arkadaş desteğidir. Üniversite eğitimi ile birlikte hem mekânsal olarak hem de duyugusal olarak aileden uzaklaşan gençlerin, tamamen yabancisı oldukları yeni bir ortama ve çevreye uyum, akademik başarı kaygısı, seçtiği meslek alanı ile ilgili gelecek kaygıları nedeniyle stres yaşadıkları ve sosyal desteğe ihtiyaç duydukları bilinen bir gerçektir. Bu nedenle üniversite eğitimi yıllarında arkadaş iletişimi ve desteği daha ön plana çıkmaktadır. Yapılan çalışmalar arkadaş ilişkilerinin kalitesi ve niteliğinin mutluluktaki en önemli belirleyici olduğunu ortaya koymaktadır (Gördesli, 2017, s.52). Paylaşma fedakarlık, hoşgörü sevgi gibi değerleri içeren sağlıklı arkadaşlık ilişkileri, bireyi mutlu eden, problem çözme, kendilik değeri ve stresle baş etme gibi (Candan ve Yalçın, 2018) durumlarda psikolojik iyi oluşuna katkı sağlayan bir sosyal sermayedir.

Bu çalışmada üniversite öğrencilerinin sosyal ilişki ve sosyal destek ağlarının belirlenmesi ve bu ilişki ağlarını etkileyen faktörlerin ortaya çıkarılmasına odaklanılmıştır. Konya' da lisans öğrenimi gören sosyal hizmet bölümü 
öğrencilerinin sosyal ilişki ağları, algılanan anne baba tutumu, akademik başarı, sosyal medya kullanım sıklı̆̆ı gibi bağımsız değişkenler açısından araştırılmıştır. Bir sosyal bilim alanı ve meslek olarak sosyal hizmet; sosyal yardımlaşma ve dayanışma temelinde inşa edilen, kuruluş felsefesini insanın refahı ve gelişimi üzerine temellendiren bir disiplindir (Beki ty., s.6). Genelde tüm insanların işlevselliği için çalısssa da ayrımcılığa, baskıya uğramış, dışlanmış, toplumun en savunmasız kesimlerine öncelik vermektedir (Sheafor, Horejsi, 2014, s.23). Sosyal hizmet bölümü öğrencileri gelecekte mesleklerini icra ederken toplumun en dezavantajlı bireylerine hizmet sunmak, müracaat eden kişilerin sosyal ekonomik yönden sahip oldukları mevcut koşulları iyileştirip destek ağlarını genişleterek güçlenmelerine yardımcı olmak durumundadır. Çünkü yoksulluktan işsizliğe, engelli bireyler ve aile sorunlarından, korunmaya muhtaç çocuk, kadın, yaşlı ihmal ve istismarına kadar tüm dezavantajlı bireyler sosyal hizmet çalışanlarının müracaatçı kitlesini oluşturmaktadır. Tüm bu alanlarda yetkin bir meslek elemanı adayı olarak öğrencilerin mesleki donanımları için temel şartlardan birisi güçlü sosyal ilişki ve iletişim ağlarına ve becerilerine sahip olmalarıdır. Müracaatçıların güçlenme sürecini yönetebilmek sosyal hizmet çalışanlarının kişisel ve mesleki güç algılarına bağlıdır (Kırlığlu ve Karakuş, 2019). Bu nedenle önce kendilerinin güçlü sosyal destek unsurlarına sahip olması, sosyal ilişki, iletişim ve etkileşim ağlarının kuvvetli olması gerekmektedir.

\section{Amaç}

Bu çalışmada Sosyal Hizmet Bölümü öğrencilerinin sosyal ilişki unsurları ve bu unsurlara etki eden faktörlerin belirlenmesi amaçlanmıştır. Bu amaç doğrultusunda aşağıdaki problemlere cevap aranmıştır.

1. Sosyal Hizmet Bölümü öğrencilerinin sosyal ilişki unsurları ve sosyal destek ağları öğrencilerin anne-baba tutumlarına göre farklılaşmakta midır?

2. Sosyal Hizmet Bölümü öğrencilerinin sosyal ilişki unsurları ölçeği toplam puan ortalamaları sosyal medya kullanım düzeyine göre farklılaşmakta midır?

3. Sosyal Hizmet Bölümü öğrencilerinin sosyal ilişki unsurları ölçeği toplam puan ortalamaları akademik başarı düzeylerine göre farkl1laşmakta mıdır? 


\section{Metodoloji}

Bu araştırma Sosyal Hizmet Bölümü öğrencilerinin sosyal ilişki unsurlarının bağımsız değişkenlere göre değişip değişmediğini inceleyen ilişkisel tarama modelinde betimsel bir çalışmadır.

\section{Evren ve Örneklem}

Araştırmanın evrenini Konya Merkez ve Beyşehir ilçesinde 2'si devlet 1'i özel üniversitede öğrenim gören 911 sosyal hizmet lisans öğrencisi oluşturmaktadır. Bilinen evren örneklem büyüklüğü hesabına göre araştırma için uygun örneklem büyüklüğü 278 olarak gösterilmektedir (Yazıcıoğlu ve Erdoğan, 2004, s.49-50; Sencer 1989, s.609). Araştırmada evreninin tamamına ulaşmak hedeflenmiştir. Fakat ulaşılabilen, geri dönen ve hatalı veriler ayıklandıktan sonra \%95 güven aralığı, 0,05 hata payı ile işleme alınan örneklem sayısı 310 olarak gerçekleşmiştir.

\section{Veri Toplama Araçları}

Veriler online anket sistemi üzerinden 2019-2020 Eğitim Öğretim yılı Bahar döneminde toplanmıştır. Öğrencilere araştırma hakkında bilgi de içeren anket formu sosyal medya (facebook grupları) watsapp ve e-mail yoluyla ulaştıılmış, araştırmaya katılımın gönüllülük esasına dayandığı, devam etmek istemedikleri zaman sonlandırabilecekleri belirtilerek onamları alınmıştır. Anket formu 12 sorudan oluşan kişisel bilgi formu ile Turner, Levin ve Frankel (1983) tarafından geliştirilen, Duyan Gelbal ve Çalık Var (2013) tarafından Türkçeye uyarlama çalışması yapılan sosyal ilişki unsurları ölçeğinden oluşmaktadır.

Kişisel Bilgi Formu: Kişisel bilgi formunda cinsiyet, yaş, sosyoekonomik durum, başarı durumu, annenin eğitim düzeyi, babanın eğitim düzeyi, anne ve baba tutumu ve sosyal medya kullanma sıklığı sorulmuştur.

Sosyal İlişki Unsurları Ölçeği: Turner, Levin ve Frankel (1983) tarafından geliştirilen sosyal ilişki unsurları ölçeğinin Türkçeye uyarlama çalışmaları Duyan, Gelbal ve Çalık Var (2013) tarafından yapılmıştır. Ölçeğin aile des- 
teği ve arkadaş desteği olmak üzere iki alt boyut vardır ve 15 maddeden oluşmaktadır. Ölçekte yer alan soruların ikisi olumsuz (7 ve 15), on üçü de olumlu nitelik taşımaktadır. Olumlu sorular için verilen yanıtlar, 1-Benim için asla geçerli değil, 2-Benim için pek geçerli değil, 3-Benim için biraz geçerli, 4-Benim için oldukça geçerli, 5-Benim için tamamıla geçerli şeklindedir. Ölçekten elde edilebilecek en düşük puan 15, en yüksek puan $75^{\prime}$ tir. Ölçekten alınılan yüksek puan kişilerin çevresinden sosyal desteği daha çok aldığını düşündüklerini göstermektedir.

Geçerlik ve güvenirlik çalışmaları Duyan, Gelbal ve Çalık Var (2013) tarafından yapılan ölçeğin Cronbach Alpha katsayısı .81 bulunmuştur. Bu çalışmada ölçeğin cronbach alfa katsayısı ,877 olarak bulunmuştur.

\begin{tabular}{lll}
\hline Reliability Statistics & & \\
\hline Cronbach's Alpha & $\begin{array}{l}\text { Cronbach's Alpha Based on Standar- } \\
\text { dized Items }\end{array}$ & N of Items \\
\hline, 877 &, 882 & 15 \\
\hline
\end{tabular}

\section{Sinırliliklar}

Bu araştırma Konya'da üç farklı üniversitede öğrenim gören ve araştırmaya gönüllü katılım sağlayan sosyal hizmet bölümü öğrencileriyle sınırlıdır.

\section{Verilerin Analizi}

Verilerin analizinde SPSS programı kullanılmıştır. Önce verilerin normallik testine bakılmış, basıklık ve çarpıklık değerleri $+1 /-1$ değerlerinin üstünde bulunduğu için normal dağılım göstermediği sonucuna varılmıştır. Bu nedenle ikili değişkenler için Mann- Whitney U testi, çoklu değişkenler için Kruskal Wallis testi ve Frekans analizi uygulanmıştır.

\section{Etik}

Bu çalışma için Necmettin Erbakan Üniversitesi Sosyal ve Beşeri Bilimler Araştırma ve Yayın Etiği Kurulundan 2020/56 sayılı karar ile izin alınmıştır. Öğrencilere anketi cevaplamadan önce bilgilendirme notu gönderilmiş onamları alınmıştır. 


\section{Bulgular}

Örneklemin \%80'i kadın, \%19,4'ü erkek öğrencidir. \%22,9'u birinci sınıf, \%30'u ikinci sınıf, \%26,5'i üçüncü sınıf, \% 20,6'sı son sınıfda öğrenim görmektedir. Örneklemin diğer tanımlayıcı bilgileri aşağıdaki tabloda verilmiştir.

Tablo 1. Katılımcıların Tanımlayıcı Özelliklerine İlişkin Frekans Dağılımı

\begin{tabular}{|c|c|c|}
\hline Gelir düzeyi & $\mathrm{n}$ & $\%$ \\
\hline Düşük & 30 & 9,7 \\
\hline Orta & 264 & 85,2 \\
\hline Yüksek & 16 & 5,2 \\
\hline \multicolumn{3}{|l|}{ Başarı Durumu } \\
\hline Düşük & 30 & $\% 4,5$ \\
\hline Orta & 215 & $\% 69,4$ \\
\hline Yüksek & 81 & 26,1 \\
\hline \multicolumn{3}{|l|}{ Anne Eğitim Durumu } \\
\hline Herhangi bir okul mezunu değil & 40 & 12,9 \\
\hline İlkokul & 172 & 55,5 \\
\hline Ortaokul & 48 & 15,5 \\
\hline Lise & 33 & 10,6 \\
\hline Üniversite & 17 & 5,5 \\
\hline \multicolumn{3}{|l|}{ Baba Eğitim Durumu } \\
\hline Herhangi bir okul mezunu değil & 1 & 0,3 \\
\hline İlkokul & 125 & 40,3 \\
\hline Ortaokul & 56 & 18,1 \\
\hline Lise & 77 & 24,8 \\
\hline Üniversite & 51 & 16,5 \\
\hline \multicolumn{3}{|l|}{ Anne-Baba Tutumu } \\
\hline Baskılı ve otoriter tutum & 28 & 9,0 \\
\hline Gevşek Tutum (Çocuk merkezci aile & 6 & 1,9 \\
\hline Dengesiz ve kararsiz tutum & 30 & 9,7 \\
\hline Koruyucu tutum & 74 & 23,9 \\
\hline İlgisiz ve kayıtsız tutum & 13 & 4,2 \\
\hline Güven verici, destekleyici ve hoşgörülü tutum & 159 & 51,3 \\
\hline \multicolumn{3}{|l|}{ Sosyal Medya Kullanım Sıklığı } \\
\hline Sik sik- her zaman & 204 & 65,8 \\
\hline Orta sıklıkta & 84 & 27,1 \\
\hline Ara sira & 22 & 7,1 \\
\hline Toplam & 310 & 100,0 \\
\hline
\end{tabular}

Tablo 1'in verilerine göre örneklemin $\% 85,2$ 'si gelir düzeyini ; \%69'u başarı durumunu "orta" olarak değerlendirmektedir. Anne eğitim durumu \%55 oranında İlkokul,\%5 oranında üniversite iken baba eğitim durumu 
\%40 ilkokul, \% 16.6 üniversite mezunu olduğu görülmektedir.. Katılımcıların \%51,3'ü anne baba tutumlarını demokratik (güven verici, destekleyici, hoşgörülü) olarak değerlendirmişlerdir. Öğrencilerin \%65,8 ‘ i sosyal medya kullanım durumunu "sık ve her zaman" olarak belirtmişlerdir.

Tablo 2. Sosyal İlişki Unsurlan Ölçek Maddelerinin Ortalama ve Standart Sapmaları

\begin{tabular}{|c|c|c|c|}
\hline & İfadeler $(\mathrm{n}=310)$ & Ort. & Std. \\
\hline 1 & $\begin{array}{l}\text { Arkadaşlarımla birlikteyken, kendim olabiliyorum ve rahatla- } \\
\text { yabileceğimi hissediyorum }\end{array}$ & 4,00 & 0,865 \\
\hline 2 & $\begin{array}{l}\text { Birçok arkadaşımla hayatla ilgili konularda ortak bakış açısına } \\
\text { sahibim. }\end{array}$ & 3,53 & 0,787 \\
\hline 3 & Beni tanıyanlar, bana güvenir ve saygı duyar. & 4,45 & 0,583 \\
\hline 4 & $\begin{array}{l}\text { Ne olursa olsun, ihtiyacım olduğunda ailemin yanımda olaca- } \\
\text { ğını bilirim. }\end{array}$ & 4,40 & 0,817 \\
\hline 5 & $\begin{array}{l}\text { Bir şeyler yapmak için dışarı çıkmak istediğimde, birçok arka- } \\
\text { daşımın bunları benimle birlikte yapmaktan hoşlanacağını } \\
\text { bilirim }\end{array}$ & 3,99 & 0,840 \\
\hline 6 & Her şeyimi anlatabileceğim en az bir arkadaşım var. & 4,17 & 1,115 \\
\hline 7 & $\begin{array}{l}\text { Bazen aileme tamamıla güvenebileceğim konusunda emin } \\
\text { olamıyorum }\end{array}$ & 3,60 & 1,158 \\
\hline 8 & Beni tanıyanlar, yaptığım işte iyi olduğumu bilirler & 4,00 & 0,811 \\
\hline 9 & Bazı arkadaşlarıma kendimi çok yakın hissediyorum. & 4,27 & 0,857 \\
\hline 10 & Ailemdeki insanlar bana güvenir. & 4,39 & 0,732 \\
\hline 11 & $\begin{array}{l}\text { Ailem değerli bir insan olduğumu düşündüklerini bana hisset- } \\
\text { tirir. }\end{array}$ & 4,09 & 0,942 \\
\hline 12 & $\begin{array}{l}\text { Ailemdeki insanlar sorunlarıma çözüm bulmamda yardımcı } \\
\text { olur. }\end{array}$ & 3,99 & 0,975 \\
\hline 14 & Ailemin her zaman bana destek vereceğini bilirim. & 4,28 & 0,876 \\
\hline 15 & $\begin{array}{l}\text { Arkadaşlarımla olduğum zamanlarda bile kendimi yalnız } \\
\text { hissediyorum }\end{array}$ & 3,59 & 1,041 \\
\hline
\end{tabular}

Araştırmaya verilen cevaplardan en yüksek ortalamayı "Beni tanıyanlar, bana güvenir ve sayg1 duyar" ( $\bar{x}=4.45)$ ifadesi, en düşük ortalama ise "Birçok arkadaşımla hayatla ilgili konularda ortak bakış açısına sahibim" ifadesi $(\bar{x}=3.53)$ almıştır.Örneklemin ailelerinin kendilerine olan güveni ve değerli bir insan olduklarını hissettirdikleri yönündeki ifadelerden aldıkları puan ortalamaları oldukça yüksek düzeydedir. Arkadaş ilişkilerinde "Birçok arkadaşımla hayatla ilgili konularda ortak bakış açısına sahibim"ifadesinden alınan puan ortalaması kısmen düşüktür. Bu da öğrencilerin farklı dünya görüşü ve farklı yaşam tarzlarına sahip olmayı sosyal ilişkilerde ve arkadaş ilişkilerinde sorun etmedikleri şeklinde yorumlanabilir. 
Tablo 3. Katılımcıların Sosyal İlişki Unsurlarn Ölçeği ve Alt Boyutlarından Aldıklarn Puan Ortalama ve Standart Sapmalarn

\begin{tabular}{llll}
\hline Ölçek Toplam ve Alt Boyutları & Ortalama \pm SS & Min & Max \\
\hline Sosyal İlişki Unsurları Toplam Puan & $60,7548 \pm 8,16960$ & 37,00 & 75,00 \\
\hline Aile Desteği Alt Boyut & $24,7645 \pm 4,34805$ & 11,00 & 30,00 \\
\hline Arkadaş desteği Alt Boyut & $35,9903 \pm 5,19365$ & 19,00 & 45,00 \\
\hline
\end{tabular}

Katılımcıların sosyal ilişki unsurları ölçeğinden aldıkları minimum puan 37,00'dır. Maximum puan ise 75,00'dır. Katılımcıların aldıkları arkadaş desteği $(\bar{x}=35,99)$ aile desteğinden $(\bar{x}=24,76)$ daha fazladır.

Tablo 4. Katılımcıların Akademik Başarı Durumlan ile Ölçek Puan Ortalamalarının Karşılaştırılması

\begin{tabular}{lllllll}
\hline Ölçekler & Başarı & Du- & $\mathrm{N}$ & Ortalama & SS & $\begin{array}{c}\text { Test İstatis- } \\
\text { tiği }\end{array}$ \\
\hline Aile Desteği & Düşük & 14 & 133,82 & 4,34805 & $4,173^{*}$ &, 124 \\
& Orta & 215 & 150,74 & & & \\
& Yüksek & 81 & 171,89 & & &, 025 \\
\hline Arkadaş & Düşük & 14 & 116,29 & 5,19365 & $7,346^{*}$ & \\
Desteği & Orta & 215 & 150,57 & & & \\
& Yüksek & 81 & 175,37 & & & \\
\hline
\end{tabular}

${ }^{*}$ Kruskal Wallis Testi

Aile desteği alt boyutu ile başarı arasında yapılan Kruskal Wallis testi sonuçlarına göre başarı ile aile desteği alt boyutu arasında anlamlı bir fark bulunamamıştır $(\mathrm{p}>0,05)$.

Arkadaş desteği alt boyutu ile başarı arasında yapılan Kruskal Wallis testi sonuçlarına göre akademik başarı ile arkadaş desteği alt boyutu arasında anlamlı fakat zayıf bir ilişki bulunmuştur $(p<0,05)$. Başarı seviyesi yüksek olan öğrencilerin aldıkları arkadaş desteği orta ve düşük akademik başarıya sahip olanlara göre göre daha yüksektir.

Tablo 5. Katılımcıların Anne Baba Tutumlan İle Ölçek Puan Ortalamalarının Karşılaştırilmasi

\begin{tabular}{|c|c|c|c|c|c|c|}
\hline $\begin{array}{l}\text { Ölçek_Alt } \\
\text { Boyutlar }\end{array}$ & Anne Baba Tutumu & $\mathrm{N}$ & Ortalama & SS & $\begin{array}{l}\text { Test İstatisti- } \\
\text { ği }\end{array}$ & $\bar{p}$ \\
\hline \multirow[t]{4}{*}{ Aile Desteği } & Baskilı ve otoritera tutum & 28 & 83,70 & 24,7645 & $108,331^{*}$ & ,000 \\
\hline & $\begin{array}{l}\text { Gevşek tutum }{ }^{\mathrm{b}} \text { (çocuk } \\
\text { merkezci aile) }\end{array}$ & 6 & 115,08 & & & \\
\hline & Dengesiz ve kararsiz tutum ${ }^{\mathrm{c}}$ & 30 & 70,83 & & & \\
\hline & Koruyucu tutum $^{\mathrm{d}}$ & 74 & 138,14 & & & \\
\hline
\end{tabular}




\begin{tabular}{|c|c|c|c|c|c|c|}
\hline & İlgisiz ve kayitsız tutume & 13 & 55,92 & & & \\
\hline & $\begin{array}{l}\text { Güven verici, destekleyici } \\
\text { ve hoşgörülü tutum }^{\mathrm{f}}\end{array}$ & 159 & 201,86 & & & \\
\hline \multirow{6}{*}{$\begin{array}{l}\text { Arkadaş } \\
\text { Desteği }\end{array}$} & Baskılı ve otoriter tutum $^{a}$ & 28 & 132,93 & \multirow[t]{6}{*}{5,19365} & \multirow[t]{6}{*}{$38,159^{*}$} & \multirow[t]{6}{*}{000} \\
\hline & $\begin{array}{l}\text { Gevşek tutum } \quad \text { b(çocuk } \\
\text { merkezci aile) }\end{array}$ & 6 & 139,58 & & & \\
\hline & Dengesiz ve kararsiz tutumc $^{c}$ & 30 & 92,67 & & & \\
\hline & Koruyucu tutum $^{\mathrm{d}}$ & 74 & 141,90 & & & \\
\hline & İlgisiz ve kayıtsız tutume ${ }^{\mathrm{e}}$ & 13 & 100,62 & & & \\
\hline & $\begin{array}{l}\text { Güven verici, destekleyici } \\
\text { ve hoşgörülü tutum }{ }^{\mathrm{f}}\end{array}$ & 159 & 182,75 & & & \\
\hline
\end{tabular}

Tablo 6'ya göre, aile desteği alt boyutu ve arkadaş desteği alt boyutları ile anne-baba tutum arasında Kruskal Wallis testi sonuçlarına göre anlamlı bir ilişki bulunmuştur $(p<0,05)$. Anne baba tutumları ile sosyal ilişki unsurları ölçeği aile desteği ve arkadaş desteği alt boyutları arasında yapılan PostHoc testi sonucu güven verici, destekleyici ve hoşgörülü tutum sergileyen anne ve babaya sahip öğrencilerin aldıkları aile ve arkadaş desteği anlamlı bir şekilde daha yüksektir ( $f>d>b>a>e>c$ ) .

Mean Ranks değerlerine bakıldığında da en yüksek değer her iki alt boyutta "güven verici destekleyici ve hoşgörülü tutum"un ortalaması iken (Aile desteği= 201,86 $\pm 24,7645$; Arkadaş desteği: 182,75 $\pm 5,19365$ ); en düşük ortalama $(70,83 \pm 24,7645 ; 92,67 \pm 5,19365)$ dengesiz ve kararsiz tutum puanlarinda olmuştur.

Tablo 6. Katılımcıların Sosyal Medya Kullanım Sıklı̆̆ı İle Ölçek Puan Ortalamalarının Karşılaştırılması

\begin{tabular}{|c|c|c|c|c|c|}
\hline & $\begin{array}{l}\text { Sosyal medya kul- } \\
\text { lanma sıklığınız }\end{array}$ & $\mathrm{N}$ & Mean Rank & Test İstatistiği* & $\mathrm{p}$ \\
\hline \multirow[t]{4}{*}{ Aile Desteği } & Her zaman & 83 & 157,17 & ,953 & 813 \\
\hline & Sik sik & 121 & 151,38 & & \\
\hline & Orta sıklıkta & 84 & 162,07 & & \\
\hline & Ara sira & 22 & 146,80 & & \\
\hline \multirow{5}{*}{$\begin{array}{l}\text { Arkadaş Deste- } \\
\text { ği }\end{array}$} & Her zaman & 83 & 172,35 & 11,071 & ,011 \\
\hline & Sik sik & 121 & 144,50 & & \\
\hline & Orta sıklıkta & 84 & 166,01 & & \\
\hline & Ara sira & 22 & 112,30 & & \\
\hline & Total & 310 & & & \\
\hline
\end{tabular}

${ }^{*}$ Kruskal Wallis 
Tablo 6'nın verilerine göre, sosyal medya kullanım sıklığı ile aile desteği alt boyutunda istatistiksel açıdan anlamlı bir ilişki tespit edilememiştir ( $p>0.05$ ). Arkadaş desteği alt boyutunda ise anlamlı fakat zayıf bir ilişki vardir.

Sosyal ilişki unsurları ölçeğinden alınan puanlar ile cinsiyet, yaş, sınıf, gelir düzeyi ve anne-baba eğitim düzeyi değişkenleri arasında istatistiksel açıdan anlamlı bir ilişki bulunamamıştır.

\section{Tartışma ve Sonuç}

Yaşam bir ilişkiler ve etkileşimler bütünüdür. İnsan, hayatının her döneminde değerli olduğunun hissettirilmesine, ilgi görmeye, onaylanmaya, beğenilmeye, üzülüp korktuğu ya da kaygılandığı durumlarda destek alıp teselli edilmeye ve kendisine yakın bulduğu kişilerle duygusal ve düşünsel paylaşımlarda bulunmaya (Candan ve Yalçın, 2018 ), kısaca sosyal ve duygusal desteğe ihtiyaç duymaktadır. Bu ihtiyacın karşılanması sosyal destek ağları ve kurulan sosyal ilişkilerle mümkün olmaktadır. Sosyal destek; "sosyal ağ kavramını da içeren karmaşık bir yapı" (Duyan, Gelbal, Çalık Var, 2013, s.160) olarak değerlendirilmektedir. Aile ve yakın arkadaş insana yaşamı boyunca sosyal destek sağlayan unsurların başında gelmektedir. Alan yazınında yapılan çalışmalar aileden gelen destek açısından da annenin etkisinin fazla olduğunu göstermektedir (Demirel, 2018, s.31). Üniversite öğrencileri için yeni ortama uyum sağlama, yalnızlığını giderme, akademik başarı ve psikolojik iyilik halini sürdürebilme açısından sosyal destek daha önemli hale gelmektedir.

Bu çalışmada Konya Merkez ve Beyşehir İlçesinde öğrenim gören sosyal hizmet lisans öğrencilerinin sosyal ilişki unsurları algılanan anne baba tutumu, akademik başarı ve sosyal medya kullanım sıklığı açısından incelenmiştir. Çalışmada, sosyal hizmet öğrencilerinin sosyal ilişki unsurları genel puan ortalaması 60,75 olarak bulunmuştur. Ölçeğin aile desteği alt boyutundan aldıkları puan ortalamaları $(\bar{x}=24,76)$ arkadaş desteği alt boyutundan aldıkları puan ortalamalarından $(\bar{x}=35,99)$ daha düşüktür. Ergenlikle artan bağımsızlık ve bireyleşmenin etkisiyle gençler ailelerinden fazla akran ve arkadaş gruplarıyla vakit geçirmektedir. Böylelikle ilk yetişkinliğe giriş aşaması olan üniversite eğitimi yıllarında mekânsal uzaklığın da etki- 
siyle arkadaşlık ilişkileri ve arkadaştan alınan sosyal destek daha ön plana çıkabilmektedir.

Araştırma sonuçlarına göre göre anne-baba tutumu ile sosyal ilişki unsurları aile ve arkadaş desteği alt boyutları arasında istatistiksel açıdan anlamlı bir fark bulunmuştur. Güven verici, destekleyici ve hoşgörülü tutum sergileyen anne ve babaya sahip öğrencilerin daha fazla sosyal ilişki ağlarının olduğu, aile ve arkadaş desteği aldıkları tespit edilmiştir.

Anne baba tutumlarının üniversite öğrencilerinin sosyal ilişki ve sosyal destek ağları üzerinde etkisi üzerine yapılan çalışmalar son derece sınırlıdır. Çeçen (2008) yaptığı çalışmada otoriter-baskıcı ebeveynlerin çocuklarının aileden ve arkadaşlarından daha az destek algıladıklarını, ebeveynlerini otoriter-baskıcı ve tutarsız algılayan öğrencilerin yalnızlık yaşamaları açısından risk grubu oluşturduğu sonucuna ulaşmıştır. Sağlam (2007) lise öğrencileriyle yaptığı çalışmada, anne ve baba tutumunu demokratik olarak algılayan öğrencilerin anne ve baba tutumunu ilgisiz olarak alg1layan öğrencilere göre algıladıkları sosyal desteğin daha fazla olduğunu saptamıştır. Kahriman ve Yeşilçiçek (2007) Sağlık Meslek Yüksek Okulu öğrencileri ile yaptıkları çalışmada, anne ve baba tutumunun aileden ve arkadaştan alg1ladıkları sosyal destek puan ortalamalarına etki ettiği, baskıcı-otoriter ebeveynlerin çocuklarının ailelerinden ve arkadaşlarından daha az sosyal destek aldıklarını tespit etmiştir. Akkaya (2011) ortaöğretim öğrencileriyle yaptığ1 araştırmada demokratik tutum sergileyen ailelerden gelmiş olan öğrencilerin aile ve arkadaş destek düzeyi koruyucu ve otoriter tutum sergileyen ailelerden gelmiş olan öğrencilerden anlamlı bir şekilde yüksek olduğunu saptamıştır.

Araştırmada elde edilen bulgulara göre akademik başarı ile aile desteği alt boyutu arasında anlamlı bir ilişki bulunamazken; arkadaş desteği alt boyutu arasında anlamlı bir ilişki bulunmuştur. Yeşilçiçek ve Kahriman (2007) tarafından yapılan araştırmada akademik olarak kendisini başarılı algılayan öğrencilerin aileden ve arkadaştan algılanan sosyal desteğin puan ortalaması daha fazla bulunmuş fakat gruplar arasında olan farkın anlamlı olmadığı görülmüştür. Saygın (2008) üniversite öğrencilerinin sosyal destek, benlik saygısı ve öznel iyi oluş düzeylerini çeşitli değişkenler açısından incelediği çalışmasında sosyal destek arttıkça öznel iyi oluş düzeyinin de arttığını tespit etmiştir. Arkadaşlarından yeterli düzeyde destek alan öğrencilerin özgüvenleri gelişmekte, derslerde daha çok katılım sağlamaktadır. 
Okuldaki başarının da buna bağlı olarak arttı̆̆ını söylemek mümkündür. Atalay (2014) lise öğrencileriyle yapmış olduğu çalışmada ise yüksek ve orta başarı gösteren öğrencilerin düşük başarılı öğrencilere göre aldıkları sosyal desteğin daha yüksek olduğunu bulmuştur.

Araştırmanın sonuçlarına göre sosyal medya ile sosyal ilişki unsurları ve aile desteği alt boyutu arasında anlamlı bir ilişki bulunmazken; arkadaş desteği alt boyutu arasında anlamlı fakat zayıf bir ilişki bulunmuştur. Her zaman ve orta sıklıkta sosyal medya kullanan öğrenciler daha fazla arkadaş desteği almaktadır. İlköğretim ikinci kademe öğrencileriyle yapılan bir araştırmada (Baytemir 2006) interneti eğlence amacı dışında kullanan öğrencilerin internet kullanım süreleri arttıkça algıladıkları sosyal desteğin de arttığı, interneti eğlence maksadıyla kullanan öğrencilerin ise internet kullanım sürelerine göre algıladıkları sosyal destek arasında anlamlı bir farklılık olmadığı sonucuna ulaşılmıştır. Araştırmamıza göre öğrencilerin sosyal medya kullanma sıklığı arkadaş ilişkilerini olumsuz yönde etkilememektedir.

Sosyal hizmet insanların sosyal işlevselliğini geliştirme, sosyal ilişki ağlarını genişletmeye yardım eden bir meslektir (Sheafor ve Horejsi, 2014, s.24). Mesleğin gelecekteki icracısı olan sosyal hizmet bölümü öğrencilerinin sosyal ilişki ve sosyal destek mekanizmaları ile anne baba tutumlarının sosyal ilişki unsurları üzerindeki etkisi bu çalışma ile ortaya çıkarılmıştır. Anne baba tutumu öğrencinin sosyal ilişki ağlarını ve aldığı sosyal desteği güçlü bir şekilde etkilemektedir. Elde edilen sonuçlar doğrultusunda sosyal desteğin önemi ve aile tutumu konusunda eğitimcilerin ve sağllk personellerinin ailelere yönelik eğitici programlar düzenlemesi, ailelerin farkındalığını arttırmaya yönelik çalışmaların yapılması, öğrencilerin sosyal ilişki ağları ve destek mekanizmalarının tespiti ve diğer faktörlerle ilişkisinin farklı örneklem grupları ile çalışılması önerilebilir.

Teşekkür: Verilerin toplanmasındaki emeği ve katkısı için öğrencim Kübra Öztürk'e teşekkür ederim. 


\title{
EXTENDED ABSTRACT
}

\section{Evaluation of Social Relationship Elements in Social Work Department Students According to Perceived Parental Attitude and Academic Achievement \\ *}

\author{
Kübra Küçükşen \\ Necmettin Erbakan University
}

The most important feature distinguishing humans from other beings is that he creates a constantly changing and developing social life with his mind and ability to think. Social life is established with the relations, communication, and interaction of people. Any type of emotional and social support individuals can obtain from the environment they live in is possible with this network of relations. Having accurate relations and support networks is one of the most important elements contributing to personality development and living a happy life. The social relations and social support, which individuals create with their families, friends, and society, act as a buffer against all kinds of negative conditşions individuals face.

In this study, the purpose was to determine the social relations Elements of Social Services Department students and the Elements affecting these Elements. For this purpose, answers to the following questions were sought in the present study.

1. Do the social relations Elements and social support networks of students of the Social Services Department differ according to the attitudes of the parents of students?

2. Do the mean scores of the social relations Elements scale of Social Services Department students differ according to the level of social media use?

3. Do the mean scores of the social relations Elements scale of Social Services Department students differ according to their academic achievement levels?

In this context, the social relations networks of the undergraduate social services students in Konya were examined in terms of independent variables such as perceived parental attitudes, academic achievements, and frequency of social media use. The study population consisted of 911 social 
services undergraduate program students at universities 2 of which were state university and 1 a private university in the city center of Konya and Beyşehir district. According to the known universe sampling size calculation, the proper sampling size was found to be 278 for the study. After the accessible, returned and erroneous data were eliminated, the number of sampling was 310 with a $95 \%$ Confidence Interval, and 0.05 error margin. The data were collected with the online survey system in the spring semester of the 2019-2020 Academic Year. The survey form, which included information on the study, was sent to the students through social media, WhatsApp, and e-mail, and the consent of the participants was obtained by stating that participation in the study was based on volunteerism. The survey form consisted of the Personal Information Form that consisted of 12 questions, and the Social Relationship Elements Scale that was developed by Turner, Levin, and Frankel (1983), and adapted into Turkish by Duyan Gelbal and Çalık Var (2013). The SPSS Program was used in the analysis of the data, the Mann Whitney U Test was used for binary variables, and the Kruskal Wallis Test was used for multiple variables.

In the present study, the mean overall score of the social relationship elements of the social services students was found to be 60.75 . The mean score of the family support sub-dimension of the scale $(\bar{x}=24.76)$ was lower than the mean score of the friend support sub-dimension $(\bar{x}=35.99)$. Young people spend more time with their peers and friend groups than their families with the effect of increasing independence and individualization with adolescence. In this way, friendship relations and social support from friends might come to the forefront with the effects of spatial distance during university education years, which is the first stage of entering early adulthood.

According to the results of the study, statistically significant differences were detected between parental attitudes and social relationship elements, family and friend support sub-dimensions. It was determined that students with parents who had reassuring, supportive, and tolerant attitudes had more social networks and received support from family and friends. According to the findings of the study, no significant relations were detected between academic achievement and family support sub-dimension, and significant relations were detected with the friend support sub-dimension. Individuals who have higher academic success have more peer support. Although no significant relations were detected between social media and 
social relationship elements and family support sub-dimension, significant but weak relations were detected with the friend support sub-dimension. Students who use social media always and moderate frequently r5eceive more friend support.

Social services profession helps people to improve their social functionality and to expand their social networks by strengthening them. When they perform their profession in the future, the students of the social services department must provide services to the most disadvantaged individuals of the society and help the applicants to become stronger by improving their current social and economic conditions expanding their support networks. One of the basic conditions for the professional equipment of a student as a professional candidate who is competent in all these fields is having strong social relations, communication networks, and skills. The effect of social relations and social support mechanisms and parental attitudes of social services students, who are the future performers of the profession, on social relations elements was uncovered with this study. Parental attitudes affect the social network of students and the social support they receive strongly. Parental attitudes also have a decisive feature in the relations that individuals will develop in their private and social lives during their adulthood years. For this reason, it is extremely important that correct communication in the family is achieved and parental attitudes are supportive. Developing family environments where children are given unconditional value and trust, and opportunities are created allowing them to develop the willpower and sense of responsibility that can direct their own lives, are possible if the parents have loving, tolerant, and supportive attitudes.

In line with the results obtained here, it can be recommended that educators and healthcare personnel organize educational programs for families on the importance of social support and family attitudes, studies are conducted to increase awareness of families, to determine the social network and support mechanisms of students, and studies are conducted with different sampling groups on the relationship with other elements.

\section{Kaynakça / References}

Akkaya, Ç. (2011). Ortaöğretim öğrencilerinde alglanan sosyal destek ve öz-duyarlk düzeyleri. Yayımlanmamış yüksek lisans tezi, Sakarya Üniversitesi, Sakarya. 
Arslantürk Z., Amman M.T (2017). Sosyoloji: Giriş, kavramlar kurumlar, süreçler, teoriler. (11.bs). İstanbul: Çamlıca Yayınları

Atalay, R. (2014). Lise öğrencilerinin sosyal medyaya ilişkin tutumlar ile algıladıklarn sosyal destek düzeyleri arasındaki ilişki (Bahçelievler ilçesi örneği). Yayınlanmamış yüksek lisans tezi, Marmara Üniversitesi, İstanbul.

Atik Erkan, Z., Çoban Esen, A., Çok, F., Doğan, T. ve Karaman Güney, N. (2014). Akran ilişkileri ölçeği'nin Türkçeye uyarlanması: Geçerlik ve güvenirlik çalışmaS1. Kuram ve Uygulamada Eğitim Bilimleri, 14(2), 433-446.

Baumeister, R., \& Leary, M. (1995). The need to belong: Desire for interpersonal attachments as a fundamental human motivation. Psychological Bulletin, 117, 497-529. file:///C:/Users/Asus/Downloads/The_Need_to_Belong_Desire_for_Interperso.pdf

Baytemir, K. (2006). İlköğretim ikinci kademe öğrencilerinin bazı demografik özelliklerine ve algıladıklarn sosyal destek düzeylerine göre interneti kullanma amaçlarmm incelenmesi. Yayınlanmamış yüksek lisans tezi, Gazi Üniversitesi, Ankara.

Beki A. (ty). Manevi destek hizmetleri. İstanbul: İstanbul Üniversitesi Açk ve Uzaktan Eğitim Programı Yayınları.

file://C:/Users/Asus/Desktop/uzaktan\%20eğitim\%20ders\%20kitaplari/mane videstekhiz.pdf

Budak, B (1999). Çocukluk çă̆ı lösemileri ve sosyal destek sistemlerinin aile işlevlerine etkisi. Yayınlanmamış yüksek lisans tezi, Ondokuz Mayıs Üniversitesi, Samsun

Candan, K. ve Yalçın, A. F. (2018). Ergenlerin sosyal duygusal öğrenme becerilerinin sosyal ilişki unsurları ve umut düzeyi ile ilişkisinin incelenmesi. OPUS Uluslararası Toplum Araştırmalan Dergisi, 9(16), 319-348.

Cüceloğlu, D. (1997). İçimizdeki biz. Kalite bilincinin temeli. (13. bs). İstanbul Sistem Yayinclik

Cüceloğlu, D. (1998) İyi düşün doğru karar ver.Etkili yaşamın temel boyutlan üzerine Yakup beyle söyleşiler. (24. bs.) İstanbul: Sistem Yayınclik.

Çeçen, R. (2008). Öğrencilerinin cinsiyetlerine ve anababa tutum algılarına göre yalnızlık ve sosyal destek düzeylerinin incelenmesi. Türk Eğitim Bilimleri Dergisi 6(3), 415-431

Demirel, E. (2018). Ortaokul öğrencilerinin akıll telefon kullanımı ile sosyal ilişkileri. Yayımlanmamış yüksek lisans tezi. On Dokuz Mayıs Üniversitesi, Samsun.

Duyan, V., Gelbal, S. ve Çalık Var, E. (2013). Sosyal ilişki unsurları ölçeği'nin Türkçeye uyarlama çalışması. Hacettepe Üniversitesi Eğitim Fakültesi Dergisi, 44(44), 159169. 
Gördesli, M. A. (2017). Lise ve üniversite öğrencilerinde öznel iyi oluş üzerine bir araştırma: Değer, kişilik ve sosyal ilişkilerin rolü. Yayınlanmamıs doktora tezi. İstanbul Üniversitesi, İstanbul.

Kırlıŏlu, M. ve Karakuş, Ö. (2019). Sosyal hizmet uzmanlarının kişisel ve mesleki güç algıları ölçeğinin geçerlilik ve güvenirlik çalışması. Toplum ve Sosyal Hizmet, 30(1), 88-120.

Lin, J., Thompson, M. P. ve Kaslow, N. J. (2009). The mediating role of social support in the community environment psychological distress link among lowincome African American women. Journal Of Communty Psychology, 37 (4), 459-470. https://doi.org/10.1002/jcop.20307

Özyurt, B. E. (2007). Kanser hastalarının algıladıkları sosyal destek düzeyine ilişkin betimsel bir çalışma. Kriz Dergisi, 15(1), 1-15.

Palut, B. (2008). Düşünme stilleri ve anne baba tutumları arasındaki ilişki, Dokuz Eylül Üniversitesi, Buca Ĕ̆itim Fakültesi Dergisi, 24(01)11.

Sağlam, S. (2007). Lise öğrencilerinin ana-baba iletişimi sosyal destek ve ana-baba tutumu arasindaki ilişkilerin incelenmesi. Yayımlanmamış yüksek lisans tezi, Atatürk Üniversitesi Erzurum.

Saygin, Y. (2008). Üniversite öğrencilerinin sosyal destek, benlik saygısı ve öznel iyi oluş düzeylerinin incelenmesi. Yayımlanmamış yüksek lisans tezi. Selçuk Üniversitesi, Konya.

Sheafor, B.W., Horejsi, C.H., (2014). Sosyal hizmet mesleğinin çalışma alanı. (D. Baran Çiftçi ed.). Sosyal hizmet uygulaması. Temel teknikler ve ilkeler. (U. Onur, çev). Ankara: Nika yayınevi.

Sencer, M. (1989). Toplum bilimlerinde yöntem. (3. Bs.). İstanbul: Beta Yayıncllk.

Turner, R. J., Frankel, B. G., ve Levin, D. M. (1983). Social support: conceptualization, measurement, and implications for mental health. In J. R. Greeley (Ed.), Research in community and mental health (67-111). Greenvich, CT: JAI Press.

Yazıcıoğlu, Y. ve Erdoğan, S. (2004). Spss uygulamalı bilimsel araştırma yöntemleri. Ankara: Detay Yayıncllı.

Yeşilçiçek, K. ve Kahriman, İ. (2007). Karadeniz Teknik Üniversitesi Trabzon Sağllk üksekokulu öğrencilerinin aile ve arkadaşlarından algıladıkları sosyal destek düzeylerinin bazı değişkenler açsından incelenmesi. Atatürk Üniversitesi Hemşirelik Yüksekokulu Dergisi, 10(1), 10-21.

Yıldırım, İ. (2004). Algılanan sosyal destek ölçeğinin revizyonu. Eurasian Journal of Educational Research, 17, 221-236.

Yıldırım, İ. (2006). Anne baba desteği ve başarı. Ankara: Anı Yayıncllı. 
Zimet, G. D.; Dahlem, N. W.; Zimet, S.G. ve Farley, G. K. (1988). The Multidimensional scale of perceived social support. Journal of Personality Assessment, 52, 30- 41.

\section{Kaynakça Bilgisi / Citation Information}

Küçükşen, K. (2021). Sosyal hizmet bölümü öğrencilerinde sosyal ilişki unsurlarının algılanan anne-baba tutumu ve akademik başarıya göre değerlendirilmesi OPUS-Uluslararası Toplum Araştırmaları Dergisi, 17(38), 5071-5090. DOI: 10.26466/opus.784070 